\title{
PENCURIAN DALAM PERSPEKTIF KITAB UNDANG-UNDANG HUKUM PIDANA DAN HUKUM ISLAM
}

\section{CRIMINAL ACT OF THEFT IN PENAL CODE PRESPECTIVE AND ISLAMIC LAW}

\author{
Ahmad Syafii \\ Fakultas Syari'ah dan Ekonomi Islam Institut Agama Islam Negeri Palu \\ JL. Diponegoro No. 23, Palu, Central Sulawesi, Indonesia \\ Telp./Fax: +62-451-460798 Email: ahmad.syafii6544@yahoo.com
}

Submitted: Dec 14, 2017; Reviewed: Dec 27, 2017; Accepted: Dec 28, 2017

\begin{abstract}
Abstrak
Tindak pidana pencurian diatur dalam Kitab Undang-undang Hukum Pidana atau hukum positif, telah diklasifikasikan ke beberapa jenis kejahatan pencurian, mulai dari kejahatan pencurian biasa (Pasal $362 \mathrm{KUHP}$ ) diancam dengan penjara paling lama lima tahun, kejahatan pencurian dengan pemberatan (Pasal 363 KUHP) diancam dengan pidana penjara paling lama tujuh tahun, kejahatan pencurian ringan (Pasal $364 \mathrm{KUHP}$ ) diancam dengan pidana penjara paling lama tiga bulan, kejahatan pencurian dengan kekerasan (Pasal 365) diancam dengan pidana paling lama dua belas tahun, kejahatan pencurian dalam keluarga (Pasal 367 KUHP) mutlak tidak dapat dilakukan penuntutan. Dalam hukum pidana Islam kejahatan dikenal dengan sebutan jarimah. Jarimah adalah segala larangan syara' yang diancam dengan hukuman had atau ta'zir. Oleh karena itu pencurian termasuk dalam jarimah menurut hukum pidana Islam yang dapat dipidana dengan hukuman had potong tangan \{QS. Al-Maidah (5):38\}. Hukuman had dengan potong tangan apabila mencapai nishab yang telah ditentukan, sedangkan hukum ta'zir dilakukan apabila tidak dipenuhi syarat-syarat pencurian yang mengharuskan hukuman had.
\end{abstract}

Kata Kunci: Hukum Islam; KUHP; Tindak Pidana Pencurian

\begin{abstract}
Crime is regulated in Indonesian Criminal Code or positive law has been classified into several types of theft crimes, ranging from theft of ordinary crimes (Article 362 of the Criminal Code) punishable with imprisonment of five years, the crime of theft by weighting (Article 363 of the Criminal Code) punishable by a maximum imprisonment of seven years, minor theft crimes (Article 364 of the Criminal Code) punishable with imprisonment of three months, theft and violent crime (Article 365 of the Criminal Code) threatened with imprisonment of twelve years, the crime of theft in the family (Article 367 of the Criminal Code) is absolutely not possible prosecution. In Islamic criminal law, crime is known as jarimah. Jarimah is any Syara' prohibition which had been threatened with had punishment or ta'zir. Therefore in jarimah theft included under Islamic criminal law may be using cut hands had punishment \{Surah Al-Maidah (5): 38\}. Had punishment by cut the hand is applied when reaching a predetermined nishab, while ta'zir law done if not fulfilled the terms of theft that requires had punishment.
\end{abstract}


Keywords: Criminal Act of Theft; Islamic Law; Penal Code

\section{PENDAHULUAN}

Pertumbuhan penduduk Indonesia semakin hari semakin bertambah, sehingga tercipta kondisi pertumbuhan penduduk yang sangat berpengaruh terhadap kondisi sosial ekonomi masyarakat, terutama menyangkut masalah pemenuhan akan kebutuhan hidup dan lapangan pekerjaan.Hal ini, mudah sekali menimbulkan kerawanan di bidang keamanan dan ketenangan hidup masyarakat, seperti terjadinya tindak pidana atau kejahatan. Terjadinya suatu tindak pidana terdapat 2 (dua) pihak yang terlibat didalamnya, yaitu pelaku dan korban. Bentuk atau macam dari suatu tindak pidana sangatlah banyak, mkisalnya pembunuhan, perampokan, pencabulan, perkosaan, penggelapan, pemerasan, pencurian serta kekerasan lainnya.

Pencurian adalah salah satu jenis kejahatan yang tidak saja melanggar normanorma sosial yang terbentuk dalam kehidupan masyarakat, tetapi lebih jauh lagi, kejahatan ini juga bisa mengganggu keharmonisan dan stabilitas masyarakat. Tindak pidana pencurian telah dirumuskan dalam Pasal 362, 363, 364, 365, 366 dan 367 KUHP. Pencurian dalam hukum positif merupakan perbuatan mengambil barang, yang sama sekali atau sebagain kepu- nyaan orang lain dengan maksud untuk memiliki barang itu dengan melawan hukum. ${ }^{1}$ Pelaku pencurian dapat dituntut sesuai dengan ketentuan hukum yang berlaku.

Sedangkan dalam hukum pidana Islam istilah kejahatan dikenal dengan sebutan jarimah. Jarimah menurut Imam Al-Mawardi adalah segala larangan syara' yang diancam dengan hukuman had atau ta'zir. ${ }^{2}$ Oleh karena itu pencurian termasuk dalam jarimah menurut hukum pidana Islam yang dapat dipidana dengan hukuman had potong tangan \{QS. Al-Maidah (5):38\} danhadits Nabi Muhammad SAW. Yang diriwayatkan Imam Bukhari: "Tidaklah dipotong tangan pencuri, kecuali pada satu dinar atau sepuluh dirham". 3 Namun, hukum potong tangan diberlakukan dalam Islam dengan mempertimbangkan syaratsyarat dan rukun yang sangat ketat.

Atas dasar ini penulis tertarik untuk melakukan pengkajian terhadap salah satu jenis perbuatan melawan hukum, dengan

${ }^{1} \mathrm{R}$. Sugandhi, KUHP dan Penjelasannya, Surabaya: Usaha Nasional Offet Printing, 1981, Hlm. 376

${ }^{2}$ A. Djazuli, Fiqh Jinayah, Jakarta: Rajawali Press, 1996, Hlm. 11

${ }^{3}$ Akademi, Pemikiran Hukum Pidana Islam Kontemporer, Yogyakarta: Fakultas Syari'ah Press, 2006, Hlm.38 
judul "Pencurian Dalam Perspektif Kitab Undang-Undang Hukum Pidana dan Hukum Islam”.

\section{ANALISIS DAN PEMBAHASAN}

Tinjauan Umum Terhadap Tindak Pidana Pencurian Dalam KUHP

Pengertian Tindak Pidana Pencurian

Dari segi bahasa (etimologi) pencurian berasal dari kata curi yang mendapat awalan pe, dan akhiran an. Menurut kamus besar bahasa Indonesia, arti dari kata "curi" adalah mengambil milik orang lain tanpa izin atau dengan tidak sah, biasanya dengan sembunyi-sembunyi. Sedangkan arti "pencurian" proses, cara, perbuatan. ${ }^{4}$

Pengertian pencurian menurut hokum beserta unsur-unsurnya dirumuskan dalam Pasal 362 KUHP yang berbunyi: barangsiapa mengambil suatu benda yang seluruhnya atau sebagian milik orang lain, dengan maksud untuk dimiliki secara melawan hukum,diancam karena pencurian, dengan pidana penjara paling lama 5 tahun atau denda paling banyak Rp.900,00-. ${ }^{5}$

Simons

$$
\text { maupun }
$$

Pompe, menyamakan bahwa arti mengambil dengan istilah wegnemen dalam KUHP Jerman yang berarti tidak diperlukan pemindahan tempat dimana barang berada, tetapi hanya memegang saja belum cukup, tersangka harus menarik barang itu kepadanya dan menempatkannya dalam kekuasaannya. ${ }^{6}$

Menurut Wirjono Prodjodikoro mengemukakan bahwa unsur-unsur tindak pidana pencurian dalam rumusan Pasal 362 KUHP sebagai berikut: Unsur pertama dari tindak pidana pencurian adalah perbuatan mengambil barang. Kata mengambil (wegnemen) dalam arti sempit terbatas pada menggerakkan tangan dan jari-jari, memegang barangnya, dan mengalihkannya ketempat lain. ${ }^{7}$

Berdasarkan rumusan diatas, maka dapat dipahami bahwa terdapat dua unsur, yakni unsur-unsur objektif (perbuatan mengambil, objeknya suatu benda, dan unsur keadaan yang melekat pada benda untuk dimiliki secara sebagian ataupun seluruhnya milik orang lain) dan unsur-unsur subjektif (adanya maksud, yang ditujukan untuk memiliki, dan dengan melawan hukum).

\footnotetext{
${ }^{4}$ Departemen Pendidikan Nasional, Kamus Besar Bahasa Indonesia, Ed-3, Jakarta: Balai Pustaka, 2005, Hlm. 225

${ }^{5}$ Soenarto Soerodibroto, KUHP dan KUHAP Dilengkapi Yurisprudensi Mahkamah Agung dan Hoge Raad, Jakarta: PT. RajaGrafindo Persada, 1996, Hlm. 220
}

\footnotetext{
${ }^{6}$ Suharto RM, Hukum Pidana Materiil, UnsurUnsur Obyektif sebagai Dasar Dakwaan, Jakarta: Sinar Grafiki, 2002, Hlm. 38

${ }^{7}$ Wirjono Prodjodikoro, Tindak-Tindak Pidana Tertentu di Indonesia, Bandung: Refika Aditama, 2003, Hlm. 15
} 
1. Jenis-jenis dan Unsur-Unsur Tindak Pidana Pencurian dalam KUHP

Dalam KUHP, tindak pidana pencurian di klasifikasikan sebagai kejahatan terhadap harta kekayaan oleh penyusun Undang-undang terdapat di buku ke-2 KUHP yang diatur mulai dari Pasal 362 sampai dengan Pasal 367. Tindak pidana pencurian dapat dibagi atas beberapa jenis, yaitu:

\section{a. Pencurian Biasa}

Pencurian biasa ini perumusannya diatur dalam Pasal 362 KUHP yang menyatakan : "Barang siapa mengambil sesuatu benda yang seluruhnya atau sebagian milik orang lain, dengan maksud untuk memiliki secara melawan hukum, diancam karena pencurian, dengan penjara paling lama 5 tahun atau denda paling banyak Rp 900". ${ }^{8}$

Berdasarkan rumusan Pasal 362 KUHP diatas, maka unsur-unsur tindak pidana pencurian (biasa) adalah sebagai berikut: (1) Unsur objektif, yang meliputi unsur-unsur: (a) mengambil, (b) suatu barang, (c) yang seluruhnya atau sebagian milik orang lain. (2) Unsur subjektif, yang

\footnotetext{
${ }^{8}$ R. Soesilo, Kitab Undang-undang Hukum Pidana (KUHP) Serta Komentar-Komentarnya Lengkap Pasal Demi Pasal, Bogor: Politea, 1996, Hlm. 249
}

meliputi unsur-unsur: (a) dengan maksud, (b) untuk memiliki barang/benda tersebut untuk dirinya sendiri, dan (c) melawan hukum.

Agar seseorang dapat dinyatakan terbukti telah melakukan tindak pidana pencurian, orang tersebut harus terbukti telah memenuhi semua unsur dari tindak pidana pencurian yang terdapat di dalam rumusan Pasal 362 KUHP. Walaupun pembentuk undang-undang tidak menyatakan dengan tegas bahwa tindak pidana pencurian seperti yang dimaksud dalam Pasal 362 KUHP harus dilakukan dengan sengaja, tetapi tidak dapat disangkal lagi kebenarannya bahwa tindak pidana pencurian tersebut harus dilakukan dengan sengaja, yakni karena undang-undang pidana yang berlaku tidak mengenal lembaga tindak pidana pencurian yang dilakukan dengan tidak sengaja. ${ }^{9}$

\section{b. Pencurian Dengan Pemberatan}

Istilah "pencurian dengan pemberatan" biasanya secara doktrinal disebut sebagai "pencurian yang dikualifikasikan". Pencurian yang dikualifikasikan ini menunjuk pada

${ }^{9}$ P.A.F. Lamintang, Delik-Delik Khusus, Kejahatan terhadap Harta Kekayaan, Bandung: Sinar Baru, 1989, Hlm. 2 
suatu pencurian yang dilakukan

dengan cara-cara tertentu atau dalam keadaan tertentu, sehingga bersifat lebih berat dan karenanya diancam dengan pidana yang lebih berat pula dari pencurian biasa. ${ }^{10}$ Pencurian dengan pemberatan atau pencurian yang dikualifikasikan diatur dalam

Pasal 363 dan 365 KUHP.

Unsur-unsur tindak pidana pencurian dengan pemberatan dapat dipaparkan sebagai berikut:

1) Pencurian dengan pemberatan yang diatur dalam Pasal 363 KUHP.

Pencurian yang diatur dalam Pasal 363

KUHP dirumuskan sebagai berikut:

(a) Diancam dengan pidana penjara paling lama tujuh tahun: Ke-1 pencurian ternak. Ke-2 pencurian pada waktu ada kebakaran, letusan, banjir, gempa bumi, atau gempa laut, gunung meletus, kapal karam, kapal terdampar, kecelakaan kereta api, huru hara, pemberontakan atau bahaya perang. Ke-3 pencurian di waktu malam dalam sebuah rumah atau pekarangan tertutup yang ada rumahnya, yang dilakukan oleh orang yang adanya di situ tidak diketahui atau tidak dikehendaki oleh yang berhak. Ke-4 pencurian yang dilakukan oleh dua orang atau lebih secara bersama-sama. Ke-5 pencurian yang untuk masuk ke tempat melakukan kejahatan, atau untuk sampai pada barang yang diambilnya, dilakukan

\footnotetext{
${ }^{10}$ Wirjono Prodjodikoro, Op.Cit., Hlm.19
}

dengan membongkar, merusak atau memanjat atau dengan memakai anak kunci palsu, perintah palsu atau pakaian jabatan (seragam) palsu.

(b) Jika pencurian yang diterangkan dalam ke-3 disertai dengan salah satu tersebut ke-4 dan ke-5, maka dikenakan pidana paling lama sembilan tahun.

2) Pencurian dengan pemberatan yang diatur dalam Pasal 365 KUHP

Pencurian dengan pemberatan kedua adalah pencurian yang diatur dalam Pasal 365 KUHP. Jenis pencurian ini lazim disebut dengan istilah "pencurian dengan kekerasan" atau popular dengan istilah "curas". Adapun yang menjadi unsur-unsur dalam Pasal 365

KUHP ini adalah sebagai berikut:

(a) Diancam dengan pidana penjara paling lama sembilan tahun, pencurian yang didahului, disertai atau diikuti dengan kekerasan atau ancaman kekerasan, terhadap orang, dengan maksud untuk mempersiapkan atau mempermudah pencurian, atau dalam hal tertangkap tangan, untuk memungkinkan melarikan diri sendiri atau peserta lainnya, atau untuk tetap menguasai barang yang dicurinya. (b) Diancam dengan pidana paling lama dua belas tahun:Ke-1 jika perbuatan dilakukan pada waktu malam dalam sebuah rumah atau perkarangan tertutup yang ada rumahnya, di jalan umum, atau dalam kereta api atau trem yang sedang berjalan. Ke-2 jika perbuatan dilakukan oleh dua orang atau lebih secara bersama-sama. Ke-3 jika masuknya ke tempat melakukan kejahatan dengan 
membongkar, merusak, atau memanjat atau memakai anak kunci palsu, perintah palsu atau pakaian jabatan palsu. Ke-4 jika perbuatan mengakibatkan luka-luka berat.

(b) Jika perbuatan mengakibatkan mati, maka dikenakan pidana penjara paling lama lima belas tahun

(c) Diancam dengan pidana mati atau pidana seumur hidup atau selama waktu tertentu paling lama dua puluh tahun, jika perbuatan mengakibatkan luka berat atau mati dan dilakukan oleh dua orang atau lebih secara bersama-sama dengan disertai oleh salah satu hal yang direngkan dalam ayat (2) ke-1 dan ke-3.

\section{c. Pencurian Ringan}

Pencurian ringan adalah pencurian yang memiliki unsur-unsur dari pencurian didalam bentuknya yang pokok, karena ditambah dengan unsur-unsur lain (yang meringankan), ancaman pidanaya menjadi diperingan. Pencurian ringan di dalam KUHP diatur dalam ketentuan Pasal 364. Termasuk dalam pengertian pencurian ringan ini dalah pencurian dalam keluarga. Rasio dimasukkannya pencurian keluarga kedalam pencurian ringan adalah oleh karena jenis pencurian dalam keluarga ini merupakan delik aduan, dimana terhadap pelakunya hanya dapat ditunutut apabila ada pengaduan. Dengan demikian, berbeda dengan jenis pencurian biasa pada umumnya yang tidak membutuhkan adanya pengaduan untuk penuntutannya.

Dengan demikian terdapat dua bentuk pencurian yang diatur dalam Pasal 364 dan Pasal 367 KUHP.

1) Pencurian Ringan

Jenis pencurian ini diatur dalam ketentuan Pasal 364 KUHP, yang menyatakan: Perbuatan yang diterangkan dalam Pasal 362 dan Pasal 363 ke-4, begitu juga perbuatan yang diterangkan dalam Pasal 365 ke-5, apabila tidak dilakukan dalam sebuah rumah atau pekarangan tertutup yang ada rumahnya, jika harga barang yang dicuri tidak lebih dari dua puluh lima rupiah, dikenai, karena pencurian ringan, pidana penjara paling lama tiga bulan atau denda paling banyak enam puluh rupiah. ${ }^{11}$

Unsur yang harus selalu ada dalam pencurian ringan ialah benda tidak lebih dari Rp 250,00. Dalam WvT pencurian ringan tidak diatur hanya KUHP kita yang mengatur hal ini. Untuk masa kini benda seharga Rp 250,00 pada saat ini relatif sangat kecil. Maka daripada itu kejahatan-kejahatan ringan perlu dihapus dari KUHP. ${ }^{12}$

2) Pencurian Dalam Keluarga

Pencurian dalam keluarga diatur dalam ketentuan Pasal 367 KUHP yang menyatakan: (a) Jika pelaku atau pembantu dalam salah satu kejahatan dalam bab ini adalah suami atau isteri dari orang yang terkena kejahatan dan tidak terpisah meja dan tempat tidur

\footnotetext{
${ }^{11}$ R. Soesilo, Op.Cit., Hlm. 250.

${ }^{12}$ Adami Chazawi, Kejahatan Terhadap Harta

Benda, Malang: Bayu Media, 2006, Hlm. 40.
} 
atau terpisah harta kekayaaan, maka terhadap pelaku atau pembantu itu, tidak mungkin diadakan tuntutan pidana. (b) Jika dia adalah suami atau isteri yang terpisah meja dan tempat tidur atau terpisah harta kekayaan, atau jika dia keluarga sedarah atau semeda, baik dalam garis lurus, maupun garis menyimpang sampai derajat kedua, maka terhadap orang itu hanya mungkin diadakan penuntutan, jika ada pengaduan dari yang terkena kejahatan. (c) Jika menuntut lembaga matriarlkhal, kekuasaan bapak dilakukan oleh orang lain dari bapak kandungnya, maka aturan tersebut ayat diatas, berlaku juga bagi orang itu.

Pencurian sebagaimana diatur dalam ketentuan Pasal 367 KUHP ini merupakan pencurian di kalangan keluarga. Artinya baik pelaku maupun korbannya masih dalam satu keluarga. Pencurian dalam Pasal 367 KUHP akan terjadi, apabila seorang suami atau isteri melakukan (sendiri) atau membantu (orang lain) pencurian terhadap harta benda isteri atau suaminya.

Menurut R. Sugandhi, bahwa istilah pencurian dalam keluarga ialah melakukan pencurian atau membantu melakukan pencurian atas kerugian suami atau istrinya, tidak dihukum, oleh karena mereka sama-sama memiliki harta benda bersama. Hal ini didasarkan pula atas alasan tata susila. Bukankah mudah dan dapat dirasakan betapa tidak pantasnya, dua orang terikat dalam tali perkawinan diadu satu melawan yang lain di muka sidang pengadilan oleh penuntut umum. Baik bagi mereka yang tunduk pada
Kitab Undang-Undang Perdata (Hukum Sipil), maupun yang tunduk pada Hukum Adat (Islam), selama tali perkawinan mereka belum terputus, maka pencurian oleh mereka atas kerugian salah satu pihak, tidak dapat dituntut. ${ }^{13}$

Berdasarkan ketentuan

Pasal 367 ayat (1) kUHP apabila suami isteri tersebut masih dalam ikatan perkawinan yang utuh, tidak terpisah meja atau tempat tidur juga tidak terpisah harta kekayaannya, maka pencurian atau membantu pencurian yang dilakukan oleh mereka mutlak tidak dapat dilakukan penuntutan. ${ }^{14}$

Jadi dapat dipahami, bahwa berat ringannya sangsi hukuman tindak pidana pencurian selalu dihubungkan dengan tindak pidana pencurian yang dilakukan.

\section{Tinjauan Umum Tentang Tindak Pi- dana Pencurian dalam Hukum Pidana Islam}

Definisi Pencurian

Secara etimologi pencurian berasal dari kata bahasa arab Al-Sariqah; saraqa yasriqu-saraqan, wa sariqan wa saraqatan, wa sariqatan wa sirqatan, yang berarti mengambil sesuatu secara sembunyisembunyi atau secara terang-terangan. ${ }^{15}$ Sedangkan menurut terminologi atau syara' pencurian adalah seseorang yang sadar dan sudah dewasa mengambil harta

\footnotetext{
${ }^{13}$ R. Sugandi, Op. Cit., Hlm.386

${ }^{14}$ Tongat, Hukum Pidana Materiil, Malang: UMM Press, 2003, Hlm.43

${ }^{15}$ Mardani, Kejahatan Pencurian dalam Hukum Pidana Islam, Jakarta: CV. INDHILL CO, 2008, Hlm. 91
} 
orang lain dalam jumlah tertentu secara sembunyi-sembunyi dari tempat penyimpanannya yang sudah maklum (biasa) dengan cara yang tidak dibenarkan oleh hukum dan tidak karena syubhat. ${ }^{16}$

Menurut Muhammad Al-Khatib AlSyarbini mengatakan bahwa sariqah secara bahasa berarti mengambil harta (orang lain) secara sembunyi-sembunyi dan secara istilah syara' adalah mengambil harta (orang lain) sembunyi-sembunyi dan zalim, diambil dari tempat penyimpanannya yang biasa digunakan untuk menyimpan dengan berbagai syarat. ${ }^{17}$

Dari beberapa rumusan di atas, dapat disimpulkan bahwa sariqah adalah mengambil barang atau harta orang lain yang terjaga di tempat penyimpanannya dengan cara sembunyi-sembunyi dan harta tersebut tidak syubhat.

\section{Unsur dan Syarat Tindakan Pencurian Unsur-Unsur Pencurian dalam Hukum Pidana Islam}

Unsur-unsur pencurian dalam hukum pidana Islam ada empat macam, sebagai berikut.

1) Tindakan mengambil (harta orang lain) secara sembunyi-sembunyi.

\footnotetext{
${ }^{16} \mathrm{Ali}$ as-Shabuni, Rowa'iul al-Bayan Tafsir ayat al-ahkam min al-Qur'an Jilid 1, Terjemahan Muammal Hamidi dan Imran A. Manan, Bairut: Daar Al-Ilmiyah, 1995, Hlm. 499. ${ }^{17}$ Nurul Irfan Masyrofah, Fiqh Jinayah, Jakarta : Amzah, 2013, Hlm. 100.
}

Dua hal yang perlu dicatat dalam unsur pertama ini. Yang pertama, adalah "tindakan mengambil" harta orang lain. Tindakan mengambil harta orang lain baru dikatakan tindakan pencurian, bilamana mencukupi tiga syarat-syarat: (a) Benda yang diambil telah dikeluarkan dari tempat penyimpanan yang layak bagi sejenisnya. (b) Benda tersebut telah diambil dan telah dikeluarkan dari kekuasaan pemiliknya. (c) Benda itu telah berada dalam kewenangan pihak pencuri. ${ }^{18}$ Jika salah satu dari ketiga syarat itu berkurang, tindakan "mengambil" tersebut belum dianggap sebagai pencurian yang dikenakan hukuman had. Karenanya, seseorang yang melakukan percobaan pencurian, misalnya, baru saja masuk kedalam sebuah rumah, atau baru mengumpulkan barang yang akan dibawa (tetapi belum terbawa dari tempat itu) tidak dianggap sebagai pencurian yang dapat dikenakan hukuman had. Kedua, tindakan mengambil dilakukan "secara sembunyi-sembunyi". Berarti pengambilan dilakukan tanpa sepengatahuan dan kerelaan pemiliknya. Jika unsur "secara sembunyi-sembunyi" ini tidak ada, misalnya pencopetan atau perampasan,

\footnotetext{
${ }^{18}$ Ahmad Wardi Muslich, Pengantar dan Asas Hukum Pidana Islam (Fikih Jinayah), Jakarta: Sinar Grafika, 2004, Hlm.83.
} 
hal itu tidak dianggap sebagai tindak pencurian yang dapat dikenakan had, tetapi diatur dalam hukuman ta'zir. Unsur kedua ini disepakati oleh para ahli fuqaha, kecuali di kalangan Zahariyah, yang menganggap tindakan percobaan mencuri dapat dianggap mencuri dan dapat dikenakan had. $^{19}$

2) Benda yang diambil adalah berupa harta

Salah satu unsur yang penting untuk dikenakannya hukuman potong tangan adalah bahwa barang yang dicuri itu harus barang yang bernilai mal (harta).Unsur kedua ini baru dianggap sempurna bila mana terdapat padanya persyaratan: (a) Benda yang dicuri harus mal mutaqawwin atau benda yang mempunyai nilai ekonomis (yang halal menurut Islam). Maka mencuri khamar, babi, bangkai, dan seterusnya tidak dikenakan sanksi potong tangan. ${ }^{20}$ (b) Harta yang dicuri berupa benda bergerak (harta yang mungkin dipindahkan dari satu tempat ke tempat lainnya). (c) Benda yang diambil berada ditempat penyimpanan. (d) Harta yang diambil sampai satu nisab. Tindak pidana pencurian baru dikenakan hukuman bagi

\footnotetext{
${ }^{19}$ Muhammad Ibnu Rusyd Al-Qurthubi, Bidayah al-Mujtahid juz II. Beirut: Daar AL-Fikr, t.th, Hlm. 338.

${ }^{20}$ Abdul Qadir Audah, Al-Tasyri' Al-Jina'y AlIslam Juz 1, Beirut: Daar Al_kitab Al-'Arabi, t.th, Hlm. 67.
}

pelakunya apabila barang yang dicuri mencapai nishab pencurian. Nishab harta pencurian yang dapat mengakibatkan hukuman had ialah 1/4 Dinar (kurang lebih seharga emas 1,62 gram), dengan demikian harta yang tidak mencapai nishab tidak dapat dipikirkan kembali, disesuaikan dengan keadaan ekonomi pada suatu tempat, benda yang diambil adalah harta orang lain. ${ }^{21}$

Dengan persyaratan ini dapat diketahui bahwa seseorang yang mengambil benda yang bukan hak milik seseorang, seperti kayu di hutan, tidak dianggap sebagai tindakan pencurian yang dikenakan had. Sedangkan apabila terdapat syubhat di dalam harta itu, akibat adanya sebagian hak pencuri dan hak pemilik harta itu, maka tindakan mencuri terhadap harta itu tidak dikenakan hukuman had. Dalam keadan ini terdapat dalil yang membolehkan karena merupakan hartanya, dan terdapat pula dalil yang melarang karena di situ terdapat pula hak orang lain.

Atas dasar pertimbangan bahwa adanya had menggugurkan hukaman had, seseorang yang mencuri harta baitul mal kepunyaan orang muslimin, tidak dapat dipotong tanganya, karena

\footnotetext{
${ }^{21}$ Umar Shihab, Ensiklopedi Hukum Pidana Islam, Bogor: PT.Kharisma Ilmu, 2006, Hlm.7778.
} 
didalamnya terdapat haknya. Dalam hal ini pelaku akan dikenakan hukuman ta'zir.

3) Adanya kesengajaan melakukan kejahatan.

Kesengajaan melakukan tindakan kejahatan ialah adanya kesengajaan mengambil harta orang lain padahal si pengambil mengatahui bahwa perbuatan itu terlarang. Adanya kesengajaan mengambil harta orang lain dipertegas dengan adanya keinginan memiliki harta yang diambil itu. Oleh sebab itu, tidak dianggap pencurian bilamana seseorang mengambil harta orang lain dan melenyapkannya di tempat itu juga. Ia tidak dikenakan hukuman had, tetapi dikenakan hukuman ta'zir dan mengganti rugi. Bilamana telah lengkap ketiga unsur ini dengan segala persyaratannya pada satu perbuatan, maka perbuatan itu dianggap sebagai tindakan kejahatan pencurian, sehingga pelakunya diancam dengan hukuman had.

\section{Syarat-Syarat Pencurian Menurut Hukum Islam}

Menurut Sayyid Sabiq bahwa syaratsyarat pencuri yang divonis dengan sanksi potong tangan adalah sebagai berikut:

(1) Taklif (cakap hukum),yaitu pencuri tersebut sudah balig dan berakal maka tidak divonis potong tangan pencuri gila, anak kecil, karena keduanya tidak mukalaf, tapi anak kecil yang mencuri dapat sanksi yang bersifat mendidik (ta'zir). Islam tidak menjadi syarat bagi pencuri karena apabila kafir dzimi atau orang murtad mencuri, makadivonis potong tangan begitu sebaliknya. (2) Kehendak sendiri atau Ikhtiar yaitu, bahwa pencuri tersebut mempunyai kehendak sendiri. Seandainya ia terpaksa untuk mencuri, maka tidak dianggap sebagai pencuri, karena paksaan meniadakan ikhtiar tidak adanya ikhtiar menggugurkan taklif. (3) Sesuatu yang dicuri itu bukan barang syubhat, jika barang tersebut syubhat, maka pencuri itu tidak divonis potong tangan, oleh karena itu orang tua (Bapak-Ibu) yang mencuri harta anaknya, tidak divonis potong tangan, berdasarkan hadits Nabi Muhammad SAW: kamu dan hartamu milik Bapakmu. ${ }^{22}$

Sedangkan pandangan Taqiyuddin Abu Bakar Al Husaini sebagaimana dikemukakan oleh Al Sadadrudi, bahwa ada beberapa syarat bagi diberlakukannya hukuman potong tangan orang yang mencuri, yaitu:

(1) Baligh, artinya telah dewasa menurut hukum syara'. (2) Anak kecil tidak dikenakan hukuman. (3) Berakal, artinya orang yang gila/secara kejiwaan tidak waras, terbebas dari hukuman. (d) Pencuri tersebut mencuri sebatas nisab yang nilainya telah mencapai seperempat dinar (4,25 gram emas) dari tempat penyimpanan harta yang rahasia. (4) Pelaku tidak mempunyai ikatan keluarga kandung dengan korban. Artinya, ia mencuri harta orang lain. Harta ayah merupakan harta keluarga dan harta anak juga dapat menjadi hak ayah/ibu. Seorang ayah atau ibu yang mencuri harta anaknya maka ia tidak

${ }^{22}$ Sayyid Sabiq, Fiqh Al-Sunnah Jilid II, Kuwait: Daar Al-Bayan, 1968, Hlm. 441. 
dipotong tangannya, demikian juga sebaliknya seorang anak yang mencuri harta kedua orangtuanya tidak dipotong tangannya. (5) Pencurian dilakukan tidak dalam keadaan terpaksa. Artinya pencuri sedari awal memang berniat untuk melakukan pencurian. Bila ada orang yang mencuri karena jiwanya terancam apabila ia tidak melakukan pencurian, maka ia tidak diperkenankan dipotong tangannya. (6) Barang yang dicuri merupakan barang berharga (bukan berupa makanan) dan halal serta tidak diragukan lagi kepemilikann$y a$. Bila ada orang yang kelaparan dan ia kemudian mencuri makanan dan tertangkap, ia tidak diperkenankan dipotong tangannya. (7) Tangan kanan pencuri di potong di batas pergelangan. Kalau ia mencuri lagi yang kedua kalinya, kaki kirinya dipotong. Kalau ia mencuri yang ketiga kalinya, tangan kirinya dipotong. Kalau ia mencuri lagi yang keempat kalinya, kaki kanannya dipotong. Kalau ia mencuri lagi setelah itu, maka baru akan dipenjara sampai ia bertaubat. $^{23}$

\section{Macam-Macam Pencurian dalam Hukum Pidana Islam}

Pencurian ditinjau dari segi hukumnya dibagi menjadi dua macam, yaitu:

\section{a) Pencurian yang hukumannya ta'zir}

Pencurian ini dibagi menjadi dua bagian. Pertama, semua jenis pencurian yang diancam dengan hukuman had, tetapi syarat-syaratnya tidak terpenuhi, atau batal akibat adanya keragu-raguan.

\footnotetext{
${ }^{23} \mathrm{Al}$-Sadadrudi,

http://disinisadat.wordpress.com.syaratdiberlakukannya-hukum-potong-tangan-bagipencuri/, diakses pada tanggal 14 November 2017
}

Contohnya seperti tindakan seorang ayah yang mengambil harta anaknya, atau tindakan seseorang yang mengambil harta musytarak (harta yang diserikatkan/milik bersama beberapa orang). Dalam hal ini, tidak dibedakan apakah tindakan tersebut termasuk dalam kategori pencurian ringan, atau termasuk ke dalam kategori pencurian berat. Kedua, tindakan mengambil harta orang lain secara terang-terangan atau dengan sepengetahuan, tanpa kerelaan, dan tanpa ada perlawanan dari pemiliknya. Tindakan iktilas, ghasab dan nahab, termasuk ke dalam lingkup bentuk yang kedua. Contoh, menjambret kalung dari leher wanita, lalu penjambret itu melarikan diri dan pemilikan barang tersebut melihatnya sambil berteriak meminta bantuan. ${ }^{24}$ Contoh yang lainnya adalah, seseorang yang merampas suatu kertas berharga yang sedang dipegang oleh pemiliknya. Tindakan tersebut tentunya tidak dapat dikatakan sebagai tindak pencurian ringan, sebab orang yang memiliki kertas tersebut mengetahui saat kertas berharganya itu diambil. Namun tidak dapat dikatakan sebagai tindak pencurian berat, sebab dalam kasus di atas tidak ada bentuk perlawanan dari pemiliknya.

\footnotetext{
${ }^{24}$ Ahmad Wardi Muslich, Op.Cit., Hlm.82.
} 
Dalam hukum Islam, tindak pencurian itu tidak keluar dari dua bentuk tindakan di atas, dimana terkadang para ulama fikih hanya menyebutkannya dengan kata pencurian saja tanpa membedakan apakah itu bentuk tindak pencurian ringan atau bentuk tindak pencurian berat. Akan tetapi, secara umum, apabila mereka berbicara tentang tindakan pencurian, maka yang dimaksudkan adalah tindak pencurian ringan. Sebab, apabila mereka berbicara tentang tindak pencurian berat, maka bahasa yang mereka gunakan adalah al-harabah (perampasan) atau qath $u$ ath-thariq (perampokan). Sementara untuk tindakan-tindakan yang lain, seperti nahab, ghasab, dan ikhtilas, maka ungkapan yang sering mereka gunakan adalah ikhtilas.

Prinsip umum yang dipegang para ulama fikih adalah mereka memberikan perhatian yang sangat besar terhadap tindakan-tindakan yang diancam dengan hukuman hudud atau qishash. Berkaitan dengan tindakan-tindakan tersebut, mereka memberi penjelasan yang sangat rinci, yang mencakup unsur-unsurnya, syarat-syaratnya dan bahkan hukumhukumnya. Tidak terdapat suatu celah pun dari tidakan-tindakan tersebut yang belum mereka jelaskan mengenai hukumnya, baik yang kecil (sepele) apalagi yang besar.

Sementara itu, untuk tindakantindakan yang diancam dengan hukuman takzir, mereka tidak memberikan penjelasan sebagaimana penjelasan yang mereka berikan terhadap tindakantindakan yang diancam dengan hukuman had kecuali untuk tindakantindakan yang mereka anggap penting saja, dan itu pun tidak mereka jelaskan secara terperinci, akan tetapi hanya terbatas pada penjelasan akan hukumhukumnya saja yang mereka sebutkan secara umum. Sekali pun mereka telah memberikan perhatian terhadap tindakan-tindakan yang diancam dengan hukuman takzir, akan tetapi masih terdapat celah-celah yang belum mereka jelaskan secara terperinci khususnya yang berkaitan dengan bentuk-bentuk hukuman, batasan setiap hukuman, kewenangan hakim dan pemerintah.

Karena kebanyakan tindakantindakan yang diancam dengan hukuman takzir itu dalam pelaksanaannya diserahkan kepada pemerintah untuk menentukan batasan-batasannya, dan bahkan untuk penentuan hukumanhukuman yang harus diberikan kepada pelaku tindak yang diancam dengan hukuman takzir tersebut. Di samping itu 
tindakan-tindakan yang diancam dengan hukuman takzir tersebut tidak dapat diuniversalkan, artinya tindakan-tindakan tersebut bersifat relatif. Sebab bisa jadi suatu tindakan itu dianggap buruk dan dilarang serta diancam dengan hukuman takzir di suatu tempat atau negara, sedang di tempat atau negara yang lain tindakan tersebut tidak dianggap sebagai suatu tindakan yang buruk dan terlarang.

Oleh karena itu, maka sangat masuk akal apabila kemudian para ulama kita terdahulu tidak terlalu memberi perhatian yang terperinci terhadap masalah-masalah yang berkaitan dengan hukuman takzir, sebagaimana perhatian yang mereka berikan terhadap tindakantindakan yang berhubungan dengan hukuman-hukuman yang sudah tetap, seperti tindakan-tindakan yang diancam dengan hukuman hudud dan hukuman qishash.

\section{b) Pencurian yang hukumanya had}

Menurut Abdul Qodir Audah bahwa pencurian dikategorikan menjadi dua bagian, yaitu pencurian ringan (sirqatus sughra) dan pencurian berat (sirqatul kubra). Pencurian ringan (sirqatus sughra) adalah:"Pencurian ringan adalah mengambil harta milik orang lain cara diam-diam, yaitu dengan jalan sembunyi-sembunyi". ${ }^{25}$ Sedangkan pengertian pencurian berat (sirqatus kubra) adalah:"Pencurian berat adalah mengambil harta milik orang lain dengan cara kekerasan dan ini disebut juga dengan merampok atau begal". ${ }^{26}$ Contoh hukuman had misalnya seseorang yang mencuri barang berharga di tempat penyimpanannya yang lebih dari batas minimal (nishab) pencurian, maka pencuri tersebut dikenakan hukuman had berupa potong tangan.

Perbedaan antara pencurian ringan dan pencurian berat adalah bahwa dalam pencurian ringan, pengambilan harta itu dilakukan tanpa sepengetahuan pemilik dan tanpa persetujuannya. Sedangkan pencurian berat, pengambilan tersebut dilakukan dengan sepengetahuan pemilik harta tetapi tanpa kerelaannya, disamping terdapat unsur kekerasan. Dalam istilah lain pencurian berat ini disebut jarimah hirobah atau perampokan. Dimasukkannya perampokan kedalam kelompok pencurian ini, sebabnya adalah karena didalam perampokan terdapat segi persamaan dengan pencurian, yaitu sekalipun jika dikaitkan dengan pemilik barang, perampokan itu dilakukan dengan terangterangan, namun jika dikaitkan dengan pihak penguasa atau petugas keamanan, perampokan tersebut dilakukan dengan sembunyi-sembunyi.

Kedua perbuatan di atas, yaitu mengambil harta orang lain secara sem-

${ }^{25}$ Abdul Qadir Audah, Op.Cit., h.214

${ }^{26}$ Ibid 
bunyi-sembunyi dan tanpa izin pemiliknya adalah syarat sahnya perbuatan pencurian berat. Apabila salah satu dari dua syarat itu tidak ada, maka tindakan itu tidak dapat dikatakan sebagai tindak pencurian ringan.

Jika seseorang mengambil beberapa barang dari suatu rumah dan pemilik rumah itu mengetahui namun ia tidak mengadakan perlawanan terhadap orang yang mengambil harta di rumahnya itu, maka perbuatan orang tersebut tidak bisa dikatakan tindak pencurian ringan, dan tidak juga dapat dikatakan sebagai tindak pencurian berat, akan tetapi di-katakan sebagai tindak ikhtilas.

Demikian juga halnya dengan perbuatan seseorang yang mengambil harta orang lain dengan seizin pemiliknya, sekalipun pemiliknya tidak melihat orang tersebut mengambil hartanya, namun karena pengambilan harta itu dilakukan dengan izin pemiliknya, maka tindakan tersebut tidak dikategorikan sebagai pencurian.

\section{Dasar Hukum Pencurian}

a. Al-Qur'an

Allah SWT telah berfirman dalam Q.S. Al-Ma'idah (5):38, yakni: "Laki-laki yang mencuri dan perempuan yang mencuri, potonglah tangan keduanya (sebagai) pembalasan bagi apayang telah mereka kerjakan dan se- bagai siksaan dari Allah.Dan Allah Maha Kuasa lagi Maha Bijaksana". ${ }^{27}$

M. Quraish Shihab menjelaskan tentang makna ayat tersebut, bahwa pencuri laki-laki dan pencuri perempuan, potonglah pergelangan tangan keduanya sebagai pembalasan duniawi bagi apa, yakni pencurian yang mereka kerjakan dan sebagai sisksaaan dari Allah yang menjadikan ia jera dan orang lain takut melakukan hal serupa. Dan Allah maha perkasa lagi maha bijaksana dalam menetapkan ketentuanketentuan-Nya. Tetapi jika ia menyadari kesalahannya dan menyesali lalu bertaubat, maka barang siapa bertaubat di antara pencuri-pencuri itu sesudah melakukan penganiayaannya yakni pencurian itu walaupun telah berlalu waktu yang lama dan memeperbaiki diri, antara lain mengembalikan apa yang telah dicurinya atau mengembalikan senilainya kepada pemiliknya yang syah, maka sesungguhnya Allah menerima taubatnya sehingga ia tidak akan disiksa di akhirat nanti. Sesungguhnya Allah maha pengampun lagi nah penyayang. ${ }^{28}$

Dalam menjatuhkan hukuman potong tangan, para ulama mempertim-

\footnotetext{
${ }^{27}$ Departemen Agama RI, Op.Cit., Hlm.165.

${ }^{28}$ M. Quraish Shihab, Tafsir Al Misbah-Volume

3, Ciputat : Lentera Hati, 2001, Hlm: 85-87.
} 
bangkan harta yang dicuri bernilai secara hukum, harus tersimpan di tempat penyimpanan yang biasa dan mencapai nisab. Jika tidak mencapai nisab, maka tidak ada hukuman potong tangan tetapi diganti dengan ta'zir (hukuman). ${ }^{29}$

Dengan demikian syari'at Islam memberi hukuman yang sangat berat atas perbuatan mencuri, dan juga menetapkan pandangan yang lebih realistis dalam menghukum seorang pelanggar (pencuri) yaitu dengan hukuman potong tangan. Tujuan dari hukuman tersebut adalah untuk memberikan rasa jera guna menghentikan kejahatan tersebut, sehingga tercipta rasa perdamaian di masyarakat. ${ }^{30}$

\section{b. Hadits}

Hadist merupakan sumber hukum yang kedua setelah al-Qur'an, hadist adalah ucapan Rasulullah SAW. Tentang suatu yang berkaitan dengan kehidupan manusia atau tentang suatu hal, ataudisebut pula sunnah Qauliyah, pengertian sunnah mencakup semua ucapan, perbuatan, dan yang di setujui (taqrir) Rasulullah saw. Kaitannya

\footnotetext{
${ }^{29}$ Abdur Rahman IDoi, Shahri'ah the Islamic Law/Tindak Pidana dalam Syari'at Islam, Terjemah Wadi Masturi, Jakarta: Rineka Cipta, 1992, Hlm. 63

${ }^{30}$ Ibid., Hlm. 65
}

dengan jarimah pencurian, dalam hadist banyak sekali disinggung, diantaranya adalah hadist yang diriwayatkan dari Aisyah ra. $^{31}$ bahwa Nabi SAW telah bersabda: "Dipotong tangan seorang pencuri karena dia mencuri 1/4 (seperempat) dinar atau lebih" (Shahih Mus$\lim$ No.3189). Apabila pencurian yang dilakukan kurang dari kadar satu nisab seperti yang telah ditentukan maka pelaku tidak dapat dikenakan hukuman had akan tetapi dikenakan ta'zir.

\section{c) Ijma'}

Ijma' merupakan hukum yang diperoleh atas kesepakatan beberapa ahli ishtisan dan mujtahid setelah Rasulullah saw., tentang hukum dan ketentuan beberapa masalah yang berkaitan dengan syari'at Islam, diantaranya yaitu masalah pencurian, karena Islam sangat melindungi harta benda dari kepemilikan yang tidak khaq. Ijma' juga dimanifestasikan sebagai yurisprudensi hakim Islam. Oleh karena itu perlu untuk dimaklumi bahwa tidak ada ijma' yang bertentangan dengan dalil Alquran ataupun Sunnah. Jika sekiranya didapatkan, maka kemungkinannya adalah dalil tersebut tidak sahih, atau

\footnotetext{
${ }^{31}$ Imam Muslim, Muhammad Fu'ad, Abdul Baqi' (ed), Sahih Muslim, Juz II. Beirut: Darul Kutub Al-Ilmiyah, 1995, Hlm. 45.
} 
dalil tersebut salah difahami, atau dalil tersebut telah dihapus hukumnya, atau justru ijma' tersebut sebenarnya cacat karena ada perselisihan yang tidak diketahui atau nukilannya tidak sahih. ${ }^{32}$

\section{d) Qiyas}

Qiyas adalah salah satu metode pengambilan hukum (istimbath) yang banyak digunakan dalam Islam, ketika ditemukan sebuah kasus yang tidak memiliki nash hukum secara pasti, tetapi memiliki unsur-unsur secara 'illat yang sama dengan sesuatu tindak pidana yang memang memiliki kejelasan nash hukum. ${ }^{33}$ Adapun jika unsur 'illatnya tindak kejahatan tersebut berbeda dengan tindak pidana yang hendak dijadikan sandaran qiyas, maka hukum qiyas tersebut dengan sendirinya menjadi batal. Contoh: pengqiyasan pencurian berat dengan hirabah (perampasan).

\section{Hukuman Untuk Tindak Pidana Pencu- rian}

Apabila tindak pidana pencurian telah terbukti dan telah memenuhi segala unsur dan syarat-syaratnya, jenis pencuri-

\footnotetext{
${ }^{32}$ Muhammad Izzi, https://muslim.or.id/19712mengenal-ijma-sebagai-dasar-hukumagama.html. diakses pada tanggal 27 November 2017

${ }^{33}$ Rahmad Syafei, Ilmu Ushul Fiqh, Bandung: Pustaka Stia, 1990, Hlm. 86.
}

an ini disebut al-sariqoh al-tammah . Tindakan pencurian seperti itu diancam dengan dua bentuk hukuman, yakni:

a) Pengganti kerugian (Dhaman)

Menurut Imam Syafi'i dan Imam Ahmad, hukuman potong tangan dan penggantian kerugian dapat dilaksanakan bersama-sama. Alasan mereka adalah bahwa dalam perbuatan mencuri terdapat dua hak, yaitu hak Allah sedangkan penggantian kerugian dikenakan sebagai imbangan dari hak manusia. $^{34}$

Menurut Imam Abu Hanifah dan murid-muridnya penggantian kerugian dapat dikenakan terhadap pencurian apabilaia tidak dikenakan hukuman potong tangan. Akan tetapi apabila hukuman potong tangan dilaksanakan maka pencuri tidak dikenakan hukuman untuk pengganti kerugian. Dengan demikian menurut mereka, hukum potong tangan dan penggantian kerugian tidak dapat dilaksanakan sekaligus bersama-sama. ${ }^{35}$ Alasan bahwa alQur'an hanya menyebutkan hukuman potong tangan untuktindak pidana pencurian, sebagaimana tercantum dalam Q.S. al-Maidah (5):38, dan tidak menyebutkan penggantian kerugian. Para ulama lebih menguatkan pendapat yang pertama bahwa pencuri harus mempertanggungjawabkan keduanya (potong tangan dan mengembalikan harta yang dicurinya), karena telah melanggar hak Allah dan hak hamba.

\section{b) Hukuman potong tangan}

Hukum potong tangan telah terjadi sejak zaman sebelum Islam sebagaimana disebutkan al-Qurthubi; sungguh telah di-

\footnotetext{
${ }^{34}$ Ahmad Hanafi, Asas-Asas Hukum Pidana Islam, Jakarta: PT. Bulan Bintang, 1993, Hlm.78.

${ }^{35}$ Ahmad Wardi Muslich, Op.Cit., Hlm.170.
} 
hukum potong tangan dizaman jahiliyah ialah Al-Walidah bin Al-Mughirah, kemudian Allah memerintahkan pula dimasa Islam. Dalam sejarah orang yang petama kali dihukum potong tangan dalam Islam oleh Rasulullah adalah Al- Khiyar bin Ady Naufal bin Abd. Manaf dan perempuan yang bernama Murrah binti Sufyan bin Abd Al-Asad dari Bani Makhzum. ${ }^{36}$ Hukuman potong tangan merupakan hukuman pokok,sebagaimana tercantum dalam QS. Al-Maidah (5):38. Hal ini berdasarkan hadis Rasulullah saw.:

Dari Aisyah, Rasulullah saw.bersabda: jangan dipotong tangan pencuri kecuali pada seperempat dinar atau lebih. (muttafaqun alaih). ${ }^{37}$

Rasulullah sendiri seperti dikemukakan oleh Ibnu Abdulbar, pernah mengeksekusi potong tangan terhadap wanita bernama Fatimah binti AlAswadbin Abdul As'ad Al-Mahzumi yang mencuri harta seseorang. ${ }^{38}$ Hukuman potong tangan dikenakan terhadap pencurian dengan teknis ulama' madzhab empat berbeda-beda. Cara yang pertama, memotong tangan kanan pencuri pada perge-

\footnotetext{
${ }^{36}$ Huzaimah Tahido Yanggo, Masail Fiqhiyah; Kajian Hukum Islam Kontemporer, Bandung: Fakultas Kedokteran dan Ilmu Kesehatan UIN Syarif Hidayatullah, 2007, Hlm. 62

${ }^{37}$ Al-Imam Aby Al-Husaini Muslim Ibn AlHajjaj Al-Qusairi An-Naisabury, Shahih Muslim, Juz 3, Arabiyah: Darul Kutubi As-Sunnah, $136 \mathrm{H}, \mathrm{Hlm} .1312$

${ }^{38}$ Ahmad Hanafi., Op.Cit., Hlm.78
}

langan tanganya. Apabila ia mencuri untuk kedua kalinya maka ia dikenakan hukum potong kaki kirinya. Apabila ia mencuri untuk tiga kalinya maka para ulama' berbeda pendapat. Menurut Imam Abu Hanifah, pencurian tersebut dikenai hukuman ta'zir dan dipenjarakan, sedangkan Imam yang lainnya, yaitu menurut Imam Malik, Imam Ahmad, dan Imam Syafi'i pencuri tersebut dikenakan potong tangan kirinya, apabila pencuri itu masih mencuri yang keempat kalinya maka dikenakan hukuman Ta'zir dan penjara seumur hidup (sampai mati) atau sampai ia bertaubat. ${ }^{39}$

\section{PENUTUP}

Dari uraian di atas dapat disimpulkan bahwa mencuri merupakan suatu tindakan mengambil harta orang lain yang terjaga dan mengeluarkan dari tempat penyimpanannya tanpa ada kerancuan (syubhat) di dalamnya dan dilakukan secara sembunyi-sembunyi. Dalam KUHP tindak pidana pencurian diatur dalam Pasal 362 KUHP yang mencakup pencurian biasa (gewone dieftal), Pasal 363 KUHPmencakup pencurian dengan pemberatan (gequalificeerde diefstal), Pasal 364 KUHP mencakuppencurian ringan (geprivelegeerde diefstal), Pasal 365 KUHP mencakup pencurian dengan kekerasan, dan

\footnotetext{
${ }^{39}$ Ahmad Wardi Muslich, Op.Cit., Hlm. 248249
} 
Pasal 367 KUHP mencakup pencurian dalam kalangan keluarga. Sedangkan dalam hukum Islam pencurian merupakan kejahatan yang wajib dikenai had berupa potong tangan sebagai hukuman maksimal, asalkan memenuhi syarat-syarat yang diperlukan menurut syari'at. Namun jika tidak memenuhi syarat untuk dapat dilaksanakan had lantaran ada subhat maka pencurian dikenakan hukuman ta'zir, yaitu sanksi yang bersifat mendidik, yang tidak ditentukan oleh syari'at, hakim mempunyai otoritas mutlak untuk menentukan hukuman yang dapat diberikan kepada pelaku tindak pidana pencurian tersebut.

\section{BIBLIOGRAFI}

Akademik, Pokja. 2006. Pemikiran Hukum Pidana Islam Kontemporer. Yogyakarta: Fakultas Syari'ah Press.

As-Shabuni, Ali, 1995. Rowa'iul al-Bayan Tafsir ayat al-ahkam min al-Qur'an Jilid 1. Terjemahan Muammal Hamidi dan Imran A. Manan, Bairut: Daar Al-Ilmiyah,

Al-Qurthubi, Muhammad Ibnu Rusyd. t.th. Bidayah Al-Mujtahidjuz II. Beirut: Dar Al-fikr.

Al-Qusairi, Al-Imam Aby Al-Husaini Muslim Ibn Al-Hajjaj An-Naisabury. Shahih Muslim. Juz 3, Arabiyah: Darul Kutubi As-Sunnah.
Audah, Abdul Qadir. t.th. At-Tasyri' AlJinaiy Al-Islamiy juz I dan II. Beirut: Dar Al-Kitab Al-'Arabi.

Chazawi, Adami. 2006. Kejahatan terhadap Harta Benda. Malang; Bayu Media.

Departemen Agama RI. 2005. Al-Qur'an dan Terjemahnya. Juz 1-30, Jakarta: Yayasan Penyelenggara Penterjemah/Pentafsir al-Qur'an.

Departemen Pendidikan Nasional. 2005. Kamus Besar Bahasa Indonesia, Ed3, Jakarta: Balai Pustaka

Djazuli, A. 1996. Fiqih Jinayah, Jakarta: Rajawali Press.

Doi, Abdur Rohman I. 1992. Shahri'ah the Islamic Law/Tindak Pidanadalam Syari'at Islam, Terj. Wardi Masturi. Jakarta: Rineka Cipta.

Hanafi, Ahmad. 1993. Asas-asas Hukum Pidana Islam. Jakarta: Bulan Bintang.

Imam Muslim, Muhammad Fu'ad, Abdul Baqi' (ed), 1995. Sahih Muslim, Juz II. Beirut: Darul Kutub Al-Ilmiyah

Lamintang, P.A.F. 1989. Delik-Delik Khusus, Kejahatan-Kejahatan Terhadap Harta Kekayaan.Bandung: Sinar Baru.

Mardani, 2008. Kejahatan Pencurian dalam Hukum Pidana Islam, Jakarta: INDHILL Co. 
Masyrofah, Nurul Irfan, 2013. Fiqh Jinayah, Jakarta: Amzah

Muslich, Ahmad Wardi. 2004. Pengantar dan Asas Hukum Pidana Islam (Fikih Jinayah). Jakarta: Sinar Grafika.

Prodjodikoro, Wirjono. 2003. TindakTindak Pidana Tertentu di Indonesia. Bandung: Refika Aditama.

Sabiq, Sayyid. 1968. Fiqh Al-SunnahJuz 2 dan 9. Kuwait: Dar Al Bayan.

Shihab, M. Quraish, 2001. Tafsir Al Misbah-Volume 3, Ciputat: Lentera Hati

Shihab, Umar. 2006. Ensiklopedi Hukum Pidana Islam. Bogor: PT. Kharisma Ilmu.

Soerodibroto, Soenarto. 1996. KUHP dan KUHAP Dilengkapi Yurisprudensi Mahkamah Agung dan Hoge Raad. Jakarta: PT. RajaGrafindo Persada.

Soesilo, R. 1996. Kitab Undang-undang Hukum Pidana (KUHP) Serta Komentar-komentarnya Lengkap Pasal Demi Pasal. Bogor: Politea
Sugandhi, R. 1981. KUHP dan Penjelasannya. Surabaya: Usaha Nasional Offset Printing.

Suharto RM. 2002. Hukum Pidana Materiil, Unsur-Unsur Obyektif sebagai Dasar Dakwaan. Jakarta: Sinar Grafika.

Syafei, Rahmad. 1990. Ilmu Ushul Fiqh. Bandung: Pustaka STIA.

Tongat. 2003. Hukum Pidana Meteriil. Malang: UMM Press.

Yanggo, Huzaimah Tahido. 2007. Masail Fiqhiyah; Kajian Hukum Islam Kontemporer. Bandung: FKIK UIN Jakarta.

\section{Sumber Lainnya:}

Al-Sadadrudi. http://disinisadat.wordpress.com.syar at-diberlakukannya-hukum-potongtangan-bagi-pencuri/.

Muhammad Izzi. https://muslim.or.id/19712mengenal-ijma-sebagai-dasarhukum-agama.html. 